International Journal of Social Science And Human Research

ISSN(print): 2644-0679, ISSN(online): 2644-0695

Volume 04 Issue 12 December 2021

DOI: $10.47191 / \mathrm{ijsshr} / \mathrm{v} 4-\mathrm{i} 12-48$, Impact factor-5.586

Page No: 3801-3807

\title{
Animal Protectionist or Animal Anti-protectionist? : Towards a Liberation of Animals from Human Oppression/ Patriarchy: A Textual Reading of Benjamin Zephaniah's
}

\section{Ignatius Nsaidzedze}

Senior Lecturer, Department of English and Cultural Studies, Faculty of Arts University of Buea

\begin{abstract}
The purpose of this paper is to examine whether Benjamin Zephaniah's famous poem "Talking Turkeys" can be labeled an animal protectionist or an animal anti-protectionist poem. Using natural and utilitarian theories of animal rights defenders, the paper argues that in the human animal relationship, the humans are the cause of the problem in the relationship not the animals and that they will benefit more if they make animals their friends. At the end of the study it has been found out that when one reads the poem Talking Turkeys', one unique vocabulary labels Benjamin Zephaniah as an animal protectionist who shows his admiration for animals which prompts his anthropomorphism towards them as well as his pointing of accusing fingers at us humans/patriarchy for being the cause of the animal suffering and killing. The poet advocates friendship with animals to replace our killing and eating their flesh/meat. On the contrary he advocates we become vegans/vegetarians implicitly when he urges us to feed turkeys with green and beans. He reminds us that turkeys have rights, feel pain and have mums, associations which we should join and they should not be artificially manufactured and should also be allowed to enjoy Christmas like receiving gifts and listening to good music. Humans we are told spoiled Christmas.
\end{abstract}

KEY WORDS: Protectionist, liberationist, oppression, patriarchy, vegan/ vegetarianism, friendship.

\section{INTRODUCTION}

Oppression has been part and parcel of human history from time immemorial especially the oppression of slaves, women and animals. With the subsequent evolution of human history we have had defenders of these three categories of creatures who have sought for the liberation or emancipation of these oppressed categories of creatures. History has defenders of women's rights like Mary Wollstonecraft, Margaret Fuller, Elizabeth Cady Stanton, the end of slavery like William Wilberforce and recently we have defenders of animal rights like Tom Regan and Peter Singer. Some of these animal rights defenders are feminists / Ecofeminists? Looking at the suffering and pains of animals which are trapped, hunted, reared, genetically farmed and modified, slaughtered, dismembered, packaged and sold or used in laboratories for experimentation by scientists with no scruples, we now have animal welfare reformers, liberationists, defenders, advocates or protectionists who set out to defend the rights of animals and this paper examines Benjamin Zehaniah as a good example of this defender of animal rights. This paper argues that human beings (especially patriarchy) are the source of problems between humans and animals and that humans will benefit more if they make animals their friends.

This paper intends to answer the following research questions: who is the problem in the human - animal relationship (humans, animals, or both)? Can an admirer of animals also be an oppressor of animals? Is Zephaniah for or against the freedom or rights of animals? What is his attitude towards meat eating? Is he a vegan / Vegetarian towards meat - eating?

Based on the hypothesis stated above and the research questions equally stated above, this paper has the following sub-headings: Religious Feasts and the Killing of Animals, Advocacy of Friendship with Animals, Admiration and Anthropomorphism of Animals, Animal Freedom and lastly Humans / Patriarchy as a Source of Problem between Animals and Human Beings.

\section{BODY}

Benjamin Zephaniah's "Talking Turkeys" is not a very long poem and in order to analyse the poem using the above mentioned rubrics, it is vital for us to first reproduce the poem. The poem is online.

"Talking Turkeys"

Benjamin Zephaniah

Be nice to yu turkeys dis Christmas

Cos' turkeys just wanna hav fun 
Turkeys are cool, turkeys are wicked

An every turkey has a mum

Be nice to yu turkeys dis Christmas,

Don't eat it, keep it alive,

It could be yu mate, and not on your plate

Say, yo! Turkey I'm on your side

I got lots of friends who are turkeys

An all of dem fear Christmas time,

Dey wanna enjoy it, dey say humans destroyed it.

An humans are out of dere mind,

Yeah, I got lots of friends who are turkeys

Dey all hav a right to a life,

Not to be caged up an genetically made up

By any farmer and his wife

Turkeys just wanna play reggae

Turkeys just wanna hip - hop

Can yu imagine a nice young turkey saying,

I cannot wait for de chop,

Turkeys like getting presents, dey

Wanna watch Christmas TV,

Turkeys hav brains an turkeys feel pain

In any ways like yu an me.

I once knew a turkey called Turkey

He said "Benji, explain to me please,

Who put de turkey in Christmas

An what happens to Christmas tree?

I said I am not too sure turkey

But itõs nothing to do wid Christmas

Humans get greedy an waste more dan need be

An business men mek loadsa cash.

Be nice to yu turkey dis Christmas

Invite dem indoors fe sum greens

Let dem eat cake an let dem partake

In a plate of organic grown beans,

Be nice to yu turkey dis Christmas

An spare dem de cut of de knife,

Join Turkeys United an dey'll be delighted

An yu, will mek new friends .

Before we analyse the poem, let us look at theories of animal rights defenders. In a paper titled "Animal Rights and Feminist Theory" in the book titled Ecofeminism: Women, Animals, Nature by Josephine Donavan, she discusses the two theories well. She writes: "Contemporary animal rights theory includes two major theoretical approaches, one based on natural rights theory and the other on utilitarianism. The major theoretician for the natural rights position is Tom Regan, whose primary statement appears in "The Case for Animal_Rights" (169). She writes,

Regan builds his case primarily by refuting Kant who had stipulated in his second formulation of the categorical imperative that "man and generally any rational being exists as an end in himself, not merely as a means" that rational beings possess "absolute worth", and that therefore they are entitled to treatment as ends. It is on the basis of their rationality that humans are identified by Kant and other Enlightenment thinkers as moral agents who are therefore entitled to such natural rights as to be treated as ends .(169). 


\section{Animal Protectionist or Animal Anti-protectionist? : Towards a Liberation of Animals from Human Oppression/}

Patriarchy: A Textual Reading of Benjamin Zephaniah's

Kant argued that animals are a means to an end (who is the man) and not an end in themselves, so they are there for man to use. She adds that,

In building his case for animal rights, Regan extends the category of those having absolute worth or inherent value to include non-rational but still intelligent non-human creatures. He does this by elaborating the distinction between moral agents (those who are capable of making rational, moral judgments) and moral patients (those who cannot make such formulations but are nevertheless entitled to be treated as ends. $(169-170)$.

She concludes:

Regan makes his case by countering Kant's theory that human moral patients (i.e. those who are severely retarded, infants, or others unable to reason) need not be treated as ends. This to Regan is unacceptable. Therefore, if one accepts both moral agents and moral patients as entitled to the basic respect implied in the notion of rights, Regan argues, it follows that non-human moral patients (animals) must be included in the category of those entitled to be treated as ends. To argue otherwise is speciesist; that is, it arbitrarily assumes that humans are worth more than other life forms. Speciesism is a concept borrowed from feminist and minority group theory. It is analogous to sexism and racism .(170).

Coming to the utilitarian theory of animal rights, she writes.

The utilitarian position in animal

rights theory has been developed principally by Peter Singer. Indeed, it is his admirable and courageous book Animal Liberation that largely galvanized the current animal rights movement. Singer's central premise derives from a key passage in Jeremy Bentham's Introduction to the Principles_of Morals and Legislation (1789). During a high tide of the natural rights doctrine, the French Revolution, Bentham wrote "The day may come when the rest of the animal creation may acquire those rights which never could have been with holden from them but by the hand of tyranny .... But a full grown horse or dog is beyond comparison a more rational, as well as a more conversable animal than an infant of a day, or a week, or even a month old. But suppose the case were otherwise, what would it avail? The question is not, can they reason? Nor, can they talk, but can they suffer?

Thus both Bentham and Rousseau advocate that natural rights or entrance into Kant's kingdom of ends, be accorded to creatures who can feel. (171).

She comments that "Their assumption is that the common condition that unites humans with animals is sensibility, the capacity to feel pain and experience pleasure" (172). She concludes:

The utilitarian's position proceeds from this premise to establish that if a creature is sentient, it has interests that are as equally worthy of consideration as any other sentient creatures interests when humans make decisions about their well - being. In Singer's words, "The capacity for suffering and enjoyment is a prerequisite for having interests. A stone for example does not have interest in the question of being kicked because it cannot suffer whereas a mouse does have such interests because it can experience pain as a result. "if a being suffer" Singer maintains, "there can be no moral justification for refusing to take that suffering into consideration..." The principle of equality requires that its suffering be counted equally with the like suffering of any other being. In short, "pain and suffering are bad and should be prevented or minimized, irrespective of the race, sex, or species of the being that suffers". This is the essence of the utilitarian animal rights position. (172).

In a paper titled "The Feminist Traffic in Animals" Carol J. Adams tells us the differences between animal rights advocates and animal welfare defenders when she writes.

The ontology of animals that accompanies animal rights theory involves distinguishing between reforms of certain practices that accept animals as usable and abolition of these practices. The goal is not bigger cages, but no cages; not bigger stalls but no veal calves; not mandated rest stops but no transporting; not careful placement of downed animals into front loader buckets, but no system that creates downed animal ,not "humans" slaughter, but no slaughter. Reform of the current system still subordinates animals to humans. Reform situates itself within the issue of animal welfare rather than animal rights, and the concern becomes the appropriate use of animal rather than the elimination of human use of animals. (205).

In "Roots; Rejoining Natural and Social History", Stephanie Lahar gives us the importance of respecting animal rights and animal welfare when she writes: 
Hunting rules among the Salish included sanctions against killing young animals, killing more than could be used and wasting meat "Fraught not only with economic but also with religious significance, animals were not to be lightly persecuted" White comments. "They were to be treated with respect and were not even to be laughed at, let alone tormented or killed without need". (95).

In a paper titled "From Heroic to Holistic Ethics; The Ecofeminist Challenge" by Marti Kheel, she tells us the similarity between animal liberationists and natural / environmental ethics when she writes:

If the cult of masculinity has been modeled on the image of predation, the field of nature ethics has been modeled on that of protection. Both animal liberation and environmental ethics spring from a common defensive reaction to the willful aggression perpetrated upon the natural world. Animal liberationists concentrate much of their energies on protecting those animals reduced to the state of inert matter or machines - that is, animals in laboratories and factory farms. Environmental ethicists, by contrast, devote themselves primarily

to protecting those parts of nature that are still "wild". But the underlying motive remains the same, namely the urge to defend and protect .(248).

\section{Religious Feasts and the Killing of Animals}

In ecofeminist circles it has been shown and proven that women and animals were used in rituals and domesticated. Lori Gruen in "Dismantling Oppression: An Analysis of the Connection Between Women and the Animals" confirms this when she writes:

In religious mythology, if not in actual practice, women often served as symbols for the uncontrollable and harmful and thus were sacrificed in order to purify the community and appease the gods. Animals too were sacrificed and it has been suggested that many animals were first domesticated not as food sources but as sacrificial creatures. Religious belief can thus also be seen as a particularly pernicious construction of women and animals as "others" to be used. (64).

For patriarchy to reach its present state or level, witches who showed a pre-patriarchal society as matriarchal, matrilineal and matrifocal were burned for science which has patriarchal characteristics to take over. In the paper "Animal Rights and Feminist Theory' Josephine Donovan says this of patriarchy.

In Beyond Power (1985) Marilyn French argues that "patriarchy is an ideology founded on the assumption that man is distinct from the animal and superior to it. The basis for this superiority is man's contact with a higher power / knowledge called god, reason, or control. The reason for man's existence is to shed all animal residue and realize fully has "divine" nature, the part that seems unlike any part owned by animals - mind, spirit, or control. French sees a Sadomasochism inherent in this cultural impulse to mutilate or kill off the animal / feminine in the self. According to French, patriarchal society has reached a frightening impasse. "Our culture, which worships above all else the power to kill, has reached this point of wishing to annihilate all that is feminine in our world" $(180-181)$.

In from 'Heroic to Holistic Ethics: The Ecofeminist Challenge" Marti Kheel says patriarchy is based on violence when she writes: The institutionalization of violence in modern society serves as legitimating function similar to that of ritual violence. For example, it is illegal for someone to beat a dog wantonly on the street, but if an experimenter beats the same dog in the protective confines of a laboratory while counting the number of times the dog vocalizes, it is considered an honorable activity and called "science". The rules of the experiment operate, like the rules of ritual to lend legitimacy to the violent act. Animal experimentation is accorded additional legitimation by borrowing the language of ritual. Animals are said to be "sacrificed" in laboratories, not killed. Behind this obfuscation of language lies the tragic belief that somehow, if animals are killed at the altar of science, human beings will be allowed to live (254).

It is this fixation on abstraction (God, Reason, ideas or the "Word") that has hampered the patriarchal mind from perceiving other forms of life in caring ways. (254).

Kheel also says patriarchy as an ideology is based on predation not on vegetarianism. She writes,

Patriarchal society is adept at truncating stories and then adapting them to its own needs. It is true, for example, that some animals are predators, however the vast majority are not. Most of the animals that humans eat are, in fact, vegetarian (cows, pigs, chicken). We are asked under patriarchy, to model our behavior not after the vegetarian animals but after the predators. The narration of predator thus becomes a convenient "pretext" to justify a wide range of violent acts. 
No other species of animal confines, enslaves and breeds other animals to satisfy its taste for flesh. Yet under patriarchy, this story remains untold. Nor are we told that predatory animals generally kill other animals only for survival reasons, that unlike, humans, these animals would not survive without eating meat. The story of predation is wrenched out of the larger context and served to us to consume. (257).

How can we solve the patriarchal problem in our societies? Kheel gives us the answer when she writes:

It means rethinking the stories that we have come to believe under patriarchy such as the belief that we must experiment on animals to save human life, or the belief that we must eat meat to lead healthy lives. As Carol Adams points out, we are brought up to accept that being eaten is the logical ending to the story of a farm animal's life. But stories such as these can only be conceived by a patriarchal mind that is unable to conceive of nature as important apart from human life. (257).

All over the world we discover that on religious feasts while human beings enjoy, the animal world or kingdom weeps because of massive killings of animals on such days. The question can be asked; who has decreed that animals be killed on religious feasts? The answer is man / patriarchy. That is why Zephaniah's poem "Talking Turkeys"' begins with the lines "Be nice to yu turkeys dis Christmas" because the poet has discovered that man or patriarchal humans have decreed that on Christmas day in England / Britain, they kill turkeys to enjoy this religious feast. In Africa we kill fowls. This first line of the poem is repeated many times in the poem. He says "Be nice to yu turkeys dis Christmas / don't eat it, keep it alive, / it could be yu mate, an not on you / plate." "I got lots of friends who are turkeys / an all of dem fear Christmas times, / destroyed it / and humans are out of dem mind". The poet goes further to say on Christmas turkeys "wanna watch Christmas TV". Zephaniah had a turkey friend who asked him, "Who decreed turkeys be killed on Christmas? "I once knew a turkey called Turkey / He said "Benji explain to me please, / who put de turkey in Christmas / An what happens to Christmas trees?" Zephaniahs answers “I said I am not too sure turkey / But itos nothing to do with Christ / mass". "'Humans get greedy an waste more / dan need be/ An business men mek loadsa cash"' On this Christmas slaughtering of turkeys, the poet ends his defence by saying "Be nice to yu turkeys dis Christmas / An spare dem de cut of de knife". If there are no religious ceremonies in the world, many animals will not be killed. Meat eating has implications in our societies. Carol J. Adams in "The Feminist Traffic in Animals" writes:

As the Ecofeminist Task Force Recommendation to the 1990 NWSA Conference argues "meat" eating has dire environmental consequences such as deforestation, soil erosion, heavy water consumption, unrecyclable animal excrement, and immense demands on energy and raw materials. Trafficking in animals also has consequences for our health. The recommendation identified the correlation between flesh consumption and heart attacks, breast cancer, colon cancer, ovarian cancer, and osteoporosis (210).

In 'Dismantling Oppression: An Analysis of the Connection Between Women and Animals' Lori Gruen writes: Of all the animals that are killed in food production, female animals fare the worst. The egg industry is the most acute example of highly centralized corporate exploitation of female animals. Meat eating and the consumption of "feminized protein" - dairy products and eggs in industrialised countries is perhaps the most prominent manifestation of a belief system in which women and animals are reduced to objects to be consumed. Animals clearly seem as pawns in a power dynamic by which man asserts his superiority. Women too are oppressed by this system, which indicates power. In times of shortage it is men who eat flesh. (74)

"From Heroic to Holistic Ethics; The Ecofeminist Challenge" Marti Kheel writes:

The story of meat eating must include not only the brutal treatment of animals on factory farms and in slaughter houses, not only the devastating impact of meat on world hunger and in human health. It must include all these and other details which it must weave together into a whole, only when we have all the details of this and other stories will we be able to act holistically with our bodies and souls (258).

\section{Friendship Advocacy with Animals}

This poem advocates that human beings become friends with turkeys. This is seen in the following lines. The poet says a turkey "it could be yu mate". He goes further urging us to make friends with turkeys as he has already done when he says "I got lots of friends who are turkeys". That line is repeated when he writes "Yeah, I got lots of friends who are turkeys". He takes us to a particular concrete relationship he had with a turkey called turkey when he writes "I once knew a turkey called Turkey" which/who asked the poet a question who decreed turkeys be killed or sacrificed during Christmas. The poem ends by urging us to become friends with turkey when he writes 'Join turkey united an dey will be delighted /An you will mek new friends ,'FOR/LIFE'. This poem therefore 


\section{Animal Protectionist or Animal Anti-protectionist? : Towards a Liberation of Animals from Human Oppression/ Patriarchy: A Textual Reading of Benjamin Zephaniah's}

begins with the strong message we stop killing turkeys on Christmass and ends that we make them our friends. If we kill turkeys it means we do not love them and if they become our friends it means we love them and by implication friendship with turkeys last for life unlike that of humans

\section{Admiration and Anthropomorphism]with Animals}

This poem shows admiration for the turkeys which leads or makes the poet to give turkeys human qualities. Admiration for the turkey is seen when the poet writes 'can yu imagine a nice young turkey\saying $\backslash$ I canot wait for the chop' He goes ahead to give human qualities to the turkey by saying 'Turkeys like getting presents, dey/wanna watch christmass TV', turkeys have brain and turkeys feel pain in many ways like yu and me,At the beginning of the poem he had said that turkeys are "just wanna have fun,/turkeys are wicked /and every turkey has a mum' At the middle of poem he says turkeys' all have a right to a life. He ends the poem by saying we should 'invite them indoors for some greens"' let them eat cake and " let them patakelin a plate of organs grown beans"'.

\section{ANIMAL FREEDOM}

This poem demonstrates Zephaniah as an advocate of animal freedom or liberation. This is seen in the poem when he writes ' $I$, $\mathrm{m}$ on your side". He says 'Dey all have a right to a life/ not to be caged up and genetically made up/ by any farmer and his wife'" He adds "Turkeys just wanna play reggae / Turkey just wanna hip - hop". This means turkeys should be allowed by human beings to have the same rights to enjoy life like human beings and not be caged like slaves. There are animals in life which are caged and their movements limited. They spend all their time in the pain and suffering in ranches or cages and when we remove them we kill them. This is the opinion of Lori Gruen in "Dismantling Oppression: An Analysis of the Connection Between Women and Animals" when she writes:

"Ranched" animals are generally confined in small wire cages for their entire lives. When they have grown to full size, they are killed in the least expensive way possible, most commonly by having their necks broken, being gassed or suffocated or by electrocution .(67).

Zephaniah is against this caging of animals. It limits their freedom. He is also against people who fabricate animals in laboratories or farms or industries to be used or eaten as meat. He wants therefore the natural reproduction of animals not artificial reproduction or production of animals. This is somehow ecofeminist. In America we have farm industries which produce these animals industrially. Zephaniah calls it in the poem "genetically made up / By any farmer and his wife".

\section{Humans / Patriarchy as a Source of Animal Suffering}

This poem establishes human beings as the source of problem between the relationship between animals and humans, not animals. Zephaniah says it all in the poem when he writes “..., dey say humans / destroyed it / An humans are out of dere mind". That means Christmas which was meant to be celebrated by both animals and humans, we humans have spoilt it by turning it to kill animals on that day and not allowing them to also enjoy it. In the poem when the turkey asked Zephaniah who decreed they be sacrificed on Christmas day and what has happened to the Christmas tree? He says human beings are the cause when he writes, 'Humans get greedy an waste more / dan need be / And business men mek loadsa cash". The poem clearly shows that in human - animal relationship, humans are to blame not animals. We see turkeys complaining about humans to the poet who confirms that we / humans are the cause / problem of animal exploitation and suffering not them as the animals suffer because they are using and exploiting them. The relationship is to the advantage or benefit of human beings.

\section{CONCLUSION}

This paper set out to assess whether Benjamin Zephaniah in his famous and best poem “Talking Turkeys' can be labeled as animal protectionist or an anti animal protectionist using natural and utilitarian theories of animal rights and liberation. The paper contends that in the human - animal relationship the humans not the animal is the source or cause of problem in human animal relationship as a result of patriarchy and also because of the biblical advantage given to man in the Book of Genesis during the story of creation when God created animal before Adam and woman after and man in his image and gave him dominion over this world including animals. The Book of Genesis thus authorizes and sanctions patriarchy. This study / paper establishes Zephaniah in this Poem "Talking Turkeys" as an animal protectionist, defender of animal rights and liberation. 4 The paper shows his admiration for animals which prompts his anthropomorphism as well as his pointing of an accusing finger at human beings for being the cause of suffering to animals who do not cause any suffering to human being. The poet advocates friendship with them. On the contrary, he advocates we become vegans or vegetarians implicitly when he urges us to feed turkeys with green. He reminds us turkeys have rights, feel pain and have mums and should not be artificially manufactured and should also be allowed to enjoy Christmas like us, receiving gifts and listening to good music. 
Animal Protectionist or Animal Anti-protectionist? : Towards a Liberation of Animals from Human Oppression/ Patriarchy: A Textual Reading of Benjamin Zephaniah's

\section{NOTES}

1. See Josephine Donovan's “Animal Rights and Feminist Theory” page 173.

2. This poem is published by Puffin Books at bemiaminzephaniah.com printed on 13/4/2021.

3. She writes "Trafficking in animals oppresses them, ontologizing them as "beings for another". In other worlds trafficking in animals makes us oppressors" (210). She says "Feminist conferences should be places where vegetarianism is practiced not meat eating" and "Through the use of the phrase "feminist traffic in animals" I wish to politicize the use of animals bodies as commodities. The serving of animal flesh at feminist conferences requires that feminists traffic in animals, that is, buy and consume animal parts and announces that we endorse the literal traffic. In animals, the production, transportation, slaughter, and packaging of animals bodies (181).

4. At en.m.wikipedia.org. Here expressing one of the views of Benjamin Zephaniah the author writes: "Animal Rights and Veganism .Zephaniah became a vegan age 13 when he read poems about "shimmering fish floating in an underwater paradise and birds flying free in the clear blue sky"

Zephaniah is an honorary patron of The Vegan Society, ViVA( Vegetarians' International Voice for Animals) and EVOLVE CAMPAIGNS and is an animal rights advocate. In 2004, he wrote the foreword to Keith Mann's book From Dusk til Down: An Insider's View of the Growth of the Animal Liberation Front. In August 2007, he announced that he would be launching the animal liberation Project alongside People for the Ethical Treatment of Animals

In February 2001,Zephaniah published The Little Book of Vegan Poems'. His name is the last of all the animal rights advocates all over the world from the past to the present.

\section{WORKS CITED}

1) Adams, Carol J. "The Feminist Traffic in Animals" in Ecofeminism: Women, Animals, Nature edited by Greta Gaard pp 195-218

2) Donovan, Josephine. "Animal Rights and Feminist Theory" in Ecofeminism: Women, Animals, Nature edited by Greta Gaard pp 167-194

3) Gaard, Greta. "Ecofeminism and Native American Cultures: Pushing the Limits of Cultural Imperialism" in Ecofeminism: Women, Animals, Native edited by Greta Gaard pp 295-314

4) Gaard,Greta. ' 'living Interconnections with Animals and Nature' in Ecofeminism; Women,Animals,Nature pp1-12

5) Lori, Gruen. "Dismantling Oppression: An Analysis of the Connection Between Women and Animals"' in Ecofeminism: Women, Animals, edited by Greta Gaard.60-90

6) Heller, Chaia. "For the Love of Nature: Ecology and the Cult of the Romantic" in Ecofeminism: Women, Animals, Nature edited by Greta Gaard pp.219-242

7) Zephaniah,Benjamin.Downloaded 13 June 2021 at en.m.wikipedia.org 